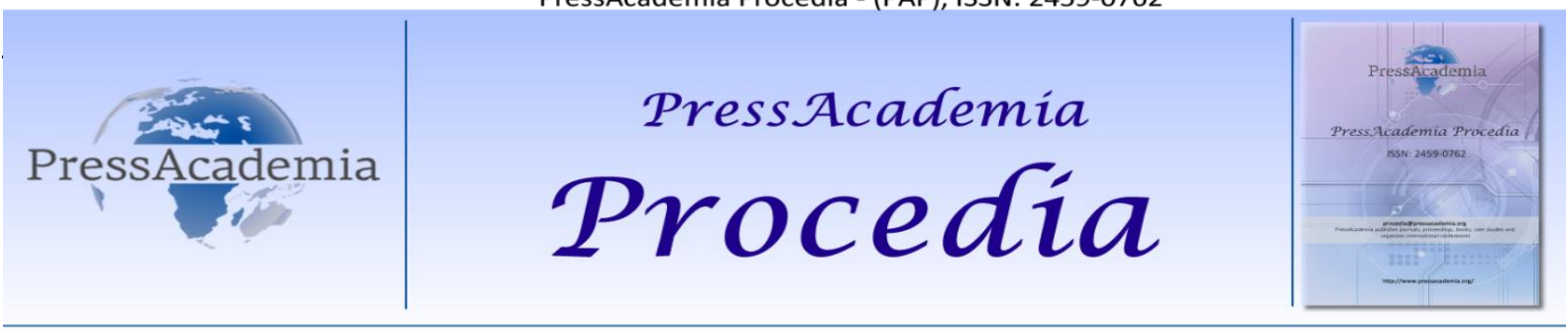

Global Business Research Congress (GBRC), May 24-25, 2017, Istanbul, Turkey.

\title{
THE RELATIONSHIP BETWEEN ORGANIZATIONAL SILENCE AND LIFE SATISFACTION IN FOOTBALL REFEREES
}

\author{
DOI: 10.17261/Pressacademia.2017.428 \\ PAP-GBRC-V.3-2017(43)-p.423-430
}

\author{
Ayhan Bayram $^{1}$, Gokhan Cetinkaya ${ }^{2}$, Yusuf Yildirim ${ }^{3}$ \\ ${ }^{1}$ Haliç University, Sütlüce Mah. Imrahor Cad. No:82 Beyoğlu. İstanbul. Turkey. ayhan bayram1987@hotmail.com \\ ${ }^{2}$ Okan University, Tuzla Kampüsü Akfırat- Tuzla. İstanbul. Turkey. gokhan.cetinkaya@okan.edu.tr \\ ${ }^{3}$ Haliç University, Sütlüce Mah. Imrahor Cad. No:82 Beyoğlu. İstanbul. Turkey. yusufyildirim@halic.edu.tr
}

\section{To cite this document}

Bayram, A, G. Cetinkaya and Y. Yildirim, (2017). The relationship between organizational silence and life satisfaction in football referees. PressAcademia Procedia (PAP), V.3, p.423-430

Permemant link to this document: http://doi.org/10.17261/Pressacademia.2017.428

Copyright: Published by PressAcademia and limited licenced re-use rights only.

\begin{abstract}
Organizational silence; It is an organizational behavior that emerges as a means of improving the organizational activities of people belonging to an organization and not expressing thoughts, ideas and suggestions that will enable the creation of disruptions, new processes and services. Life satisfaction refers to a cognitive / judicial process and is defined as the general evaluation of quality of life according to the individual's chosen criteria. The relationship between the organizational silence and life satisfaction of the footbaal referee has been examined. In order to examine on the organizational silence the "Organizational Silence" scale, which had been improved by Dyne, Ang and Botero (2003) in 2001. The scale consists of three subscale. There are 15 items on the scale. In order to examine on the life satisfaction the "life satisfaction" scale, which had been improved by Diener and friends in 1985 . This scale has been adapted into Turkish by Yetim in 1993 and has been improved and validity and reliability tests have been carried out. The scale consists of one subscale. There are 5 items on the scale. In the research was used in face to face interviews and easily using the sampling method and analyzed 114 surveys which are screened and subjected incorrect survey examined a total of 118 surveys of referee in football. Referee when applying organizational silence and life satisfaction scale, the data obtained in the light of the results were evaluated, it was seen vary of the silence and satisfaction according to demographic variables and there is a significant relationship between lower dimensions.
\end{abstract}

Keywords: Acceptance, benefit, defense, satisfaction, sport

JEL Codes: M10, M12, M19

\section{FUTBOL HAKEMLERINDE ÖRGÜTSEL SESSIZLIK ILE YAŞAM DOYUMU ARASINDAKI iLIŞKi}

\section{ÖZET}

Örgütsel sessizlik; bir örgüte mensup olan kişilerin örgüt faaliyetlerinin iyileştirilmesine, aksaklıkların ortaya çıkarılmasına, yeni süreç ve hizmetlerin oluşturulmasına olanak sağlayacak olan düşünce, fikir ve önerilerini dile getirmemeleri olarak ortaya çıkan bir örgütsel davranış olgusudur. Yaşam doyumu, bilişsel/yargısal bir sürece işaret etmekte ve bireylerin kendi seçtikleri ölçütlere göre yaşam kalitelerinin genel değerlendirmesi olarak tanımlanmaktadır. Bu araştırma da futbol hakemlerinin örgütsel sessizlik ile yaşam doyumu arasındaki ilişki incelenmiştir. Örgütsel sessizliği ölçmek amacıyla Dyne, Ang ve Botero tarafından 2003 yılında geliştirilen "örgütsel sessizlik" ölçeği kullanılmıştır. Ölçek üç alt boyuttan oluşmaktadır. Ölçekte toplam 15 madde bulunmaktadır. Yaşam doyumunu ölçmek amacıyla Diener ve arkadaşları tarafından 1985 yılında geliştirilen "yaşam doyumu” ölçeği kullanılmıştır. Bu ölçeği Yetim 1993 yılında Türkçe'ye uyarlayarak, geliştirmiş, geçerlilik ve güvenilirlik çalışmalarını yapmıştır. Ölçek bir alt boyuttan oluşmaktadır. Ölçekte toplam 5 madde bulunmaktadır. Araştırmada yüz yüze anket ve kolayda örnekleme metodu kullanılarak 118 futbol hakemi ile görüşülmüştür. Anketler incelendikten sonra hatalı olanlar elenmiş ve toplam 114 anket analize tabii tutulmuştur. Futbol hakemlerine örgütsel sessizlik ve yaşam doyumu ölçekleri uygulanarak, elde edilen veriler ışığında sonuçlar değerlendirilmiş, örgütsel sessizlik ve yaşam doyumunun demografik değişkenlere göre farklılık gösterdiği ve alt boyutları arasında anlamlı bir ilişki olduğu görülmüştür.

Anahtar Kelimeler: Kabullenmek, yarar, savunma, tatmin, spor JEL Kodları: M10, M12, M19 


\section{GiRiş}

Örgütsel Davranış biliminde, örgütsel sessizlik kavramı Morrison ve Miliken (2000) tarafından kaleme alınan "Organizational Silence: A Barrier to Change and Development in a Pluralistic World" adlı çalışma ile ortaya çıkmışır. Morrison ve Miliken (2000:707) örgütsel sessizliği; çalışanların örgütsel konu ve sorunlar hakkında fikir, görüş ve endişelerini ortaklaşa olarak esirgeme durumu olarak tanımlamışlardır. Literatürde sessizlik kavramıyla ilgili çalışmaların 2000 yılından öncede yapıldığı görülmektedir. Fakat Morrison ve Miliken (2000) sessizlik kavramını örgüt düzeyinde ve kolektif bir olgu olarak inceleyerek çalışanların sorunlar ya da problemlere bağı fikirlerini sakladığını ve bunları üstlerine iletmediğinin bilimsel anlamda yaklaşık 20 yıldır bilindiğini dile getirmişlerdir. Bu durumla ilgili olarak sistematik bir yaklaşımın geliştirilmediğini dile getiren Morrison ve Miliken (2000), örgütsel sessizliğin değişimin ve gelişimin önünde bir bariyer olduğunu ifade etmişlerdir. Çalışmalarında sessizliği daha çok iş gören sessizliği kavramıyla açıklayan Pinder ve Harlos (2001) iş gören sessizliğinin çok yönlü ve aktif bir süreç olduğunu ifade etmişlerdir. Pinder ve Harlos çalışan sessizliği kavramını; çalışmalarında adaletsizliğe gösterilen tepki olarak ele almışlar, örgütsel sessizliği ise çalışanların yapmış oldukları işe ve örgüte dair fikirlerini, değişim yapması muhtemel çalışanlardan kasıtlı ve bilinçli olarak saklamalarıd olarak tanımlamışlardır (Pinder ve Harlos, 2001: 333334).

Yaşamın hazla ve olumlu duygularla renklenmesi, zenginleşmesi hemen her bireyin istediği bir durumdur. Öte yandan yaşamın acı, keder, elem, yoksunluk, engeller, gerilimler gibi pek çok kötü öğeyi barındırdığı da bilinmektedir. Bireyin öznel ve nesnel konumlarında olumsuz koşullar birçok sarsıntıya neden olmaktadır. İnsan bilimcileri, durumsal ve bireysel özellikleri çeşitli modellerde birlikte değerlendirerek; iyi olmanın yapısını daha fazla anlamaya çalışmışlardır. İnsanın iyilik durumunu karşılayan çok sayıda sözcüğün ve kavramın olduğu bilinmektedir. Mutluluk, haz, doyum, refah, toplumsal iyi olma, yaşam kalitesi, öznel iyi olma bunlar içerisinde öne çıkanlardır. Bireyin kendi yaşamına ilişkin değerlendirmelerinin üç ayrı ancak birbiriyle ilişkili genel boyut içerisinde sınıflanabileceği öne sürülmüştür. Bunlar, olumlu duygu, olumsuz duygu ve yaşam doyumudur. Olumlu duygu boyutunda yaşanan hazların, sevinçlerin, hoş duygulanımların çokluğunun; olumsuz duygu boyutunda hoş olmayan, kötü, acı verici duyguların azlığının iyi olma açısından önemli olduğu belirlenmiştir. Yaşam doyumu ise yaşamın geneline ilişkin bilişsel yargılamaları, değerlendirmeleri kapsamaktadır (Baydar, 2003:22).

\section{LITERATÜR INCELEMESI}

Dyne, Ang ve Botero (2003) iş görenlerin temelde üç tür güdünün etkisi ile üç farklı sessizlik davranışı gösterebileceklerini belirtmişlerdir. Bu sessizlik türleri; kabullenici sessizlik, savunmacı sessizlik ve örgüt yararına sessizliktir. Kabullenici sessizlik, razı olma anlamında sessizlik ve uysal sessizlik olarak da tanımlanmaktadır. Kabullenici sessizlik; çalışanların işlerini ve örgütlerini geliştirecek-iyileştirecek fikir, bilgi ve düşüncelerini razı olma ya da kabullenme güdüsü ile kendine saklaması olarak tanımlanmıştır (Dyne ve diğerleri, 2003: 1366). Bu tür sessizliğe sahip çalışanlar, örgütün gelişiminden ümidini kesmiş ve motivasyon kapasiteleri düşmüştür (Pinder ve Harlos, 2001). İş gören örgütte konuşmanın bir farklılık ortaya koymayacağını ve olayları etkileyemeyeceğini düşünüyorsa kabullenici sessizlik davranışı sergileyebilir. Kabullenici sessizliği benimseyen iş görenler, hali hazırdaki durumu kabullenmiş ve durumu değiştirmek için herhangi bir çaba göstermemişlerdir (Dyne ve diğerleri, 2003: 166). Savunmacı sessizlik; literatürde kendini korumaya dayalı sessizlik, korkuya dayalı sessizlik, korunmacı sessizlik olarak da yer almaktadır. Savunmacı sessizlik; çalışanların korku temelli sebepler ile fikir, bilgi ve düşüncelerini esirgeyerek kendini korumasıdır (Dyne ve diğerleri, 2003: 1367; Özgen ve Sürvegil, 2009: 312; Çakıcı, 2010: 33; Taşkıran, 2011: 79). Savunmacı sessizlik, alternatifleri göz önünde bulundurmayı kapsayarak kişinin o andaki en iyi stratejinin bilgi, görüş ve düşünceleri kendine saklamak olduğuna karar verir. Savunma amaçlı sessizlikte açık bir şekilde konuşma korkusu, yeni fikirlerle dile getirilecek değişim ve gelişim önerisinin kişisel olarak riskli sonuçlar doğuracağı korkusu nedeniyle fikir ve bilgi saklanmaktadır. Örgüt yararına sessizlik, literatürde özgeci sessizlik, toplum yanlısı sessizlik, prososyal sessizlik, uzlaşmaya veya fedakârlığa dayalı sessizlik, başkalarını koruma amaçlı sessizlik olarak da yer almaktadır. Bu sessizlik türü savunmacı sessizliğin aksine, diğer iş görenler odaklıdır. Örgüt yararına sessizlikte çalışılan grup içindeki birlik ve beraberliği bozmamak gayreti ile fikirlerin esirgenmesi esastır (Dyne ve diğerleri, 2003: 1368). Örgüt yararına sessizlikte temel güdü, örgütün ve diğer bireylerin yararını gözetmektir.

Tüm sessizlik davranışlarını örgütsel sessizlik kavramıyla ilişkilendirmek doğru bir yaklaşım olmayacaktır. Sessizlik; bilerek, bir hedefe bağlı olarak ve kasıtlı bir şekilde yapıldığında örgütsel sessizliğin altında yer bulabilir. Sessizlik davranışının örgütsel sessizlik olarak değerlendirilebilmesi için, bireyin karşı tarafta değişim ve gelişim yapabilecek bilgiye sahip olduğu halde kasıtlı olarak bunu örgütle paylaşmaması durumunun oluşması gerekmektedir.

Kendilerinden önceki çalışmaları ayrıntılarıyla inceleyerek (Morrison ve Miliken, 2000; Pinder ve Harlos, 2001) sessizlik yazınına katkı sağlayan Dyne ve diğerleri (2003) sessizlik ile sesini yükseltme kavramlarının çok ayrı ve çok boyutlu olarak ele alınması gerektiğini ifade etmiş, burada iki kavramı farklı kılan şeyin konuşma eylemi olmadığını dile getirmişlerdir. Dyne ve diğerlerine göre sesini yükseltme; çalışanların örgütü iyileştirebilecek fikir ve bilgileri ifade etmesi, sessizlik ise bunları saklamasıdır. Ayrıca, Dyne ve diğerleri (2003) çalışmalarını iletişim, etik, sosyal psikoloji ve yönetim gibi alanlarla da ilişkilendirmişlerdir. 
Türk literatüründe örgütsel sessizlik kavramı Çakıcı (2007) katkıları ile yazında yer almaya başlamış ve sessizlik kavramına dikkat çekilerek konunun kavramsal temeli oluşturulmuştur. Çakıcı (2008) yapmış olduğu başka bir çalışmada iş görenlerin sessiz kaldıkları konuları, sessizliğe neden olan konuları ve sessizliğin algılanan sonuçlarını tespit etmiştir. Bu çalışmaya göre iş görenlerin sessiz kaldıkları konular; etik konular, yönetim sorunu, çalışan performansı ve iyileştirme çabalarıdır. Sessizliğe neden olan konular ise; işle ilgili korkular, tecrübe eksikliği, izolasyon korkusu yönetsel ve örgütsel hususlar ve ilişkileri zedeleme korkusudur. Sessizliğin algılanan sonuçları ise performansı engelleyen sonuçlar, iyileşmeyi engelleyen sonuçlar ve çalışanı mutsuz eden sonuçlar olarak üç grupta toplanmıştır. Çakıcı ve Aysen (2014) yaptıkları çalışmada, literatüre yönetici sessizliği kavramını kazandırmış ve yöneticilerin sessiz kalmasını etkileyen değişkenleri; üstün özellikleri, astın özellikleri, kurumun özelliği, ilişkilerin niteliği ve algılanan riskler olarak belirlemişlerdir.

Yaşam doyumu kavramı; Neugarten (1961) tarafından ortaya atılan bir kavramdır. Neugarten'e göre yaşam doyumu; kişin in yaşamdan beklentileriyle nelere sahip olduğu ilişkisinin ortaya çıkardığı sonuçtur (Neugarten ve diğerleri, 1961: 134-143). Yaşam doyumu kavramı Diener (1984) tarafından kaleme alınan "Subjective Well-Being" adlı makalede öznel iyi oluş hali ile açıklanmıştır. Diener'e göre (2001) öznel iyi oluş, bireyin kendi hayatını değerlendirmesi ve bu yönde bir sonuca ulaşması anlamını taşır. Ayrıca Diener (1984) öznel iyi oluşu, bireyin yaşamına yönelik algıladığı kalite ve doyum bakımından olumlu duyguların varlığı ve olumsuz duyguların yokluğu olarak tanımlamaktadır. Öznel iyi oluşun üç temel bileşeni bulunmaktadır. Bunlar; yaşam doyumu, olumlu ve olumsuz duygulanımlardır (Diener, 1984; Andrews ve Whitney, 1976; Eryılmaz ve Öğülmüş, 2010). Öznel iyi oluş alanı kişinin yaşamına ilişkin kendi değerlendirmesi üzerinde yoğunlaşmaktadır (Diener, 2000: 34-43. Yaşam doyumu bireyin belirlediği ölçütlere göre yaşamının niteliği hakkındaki değerlendirmesi olarak tanımlanmaktadır. Yaşam doyumu Veenhoven (1996) tarafından, bir bütün olarak yaşamın bütün kalitesinin pozitif olarak gelişiminin derecesi olarak tanımlanmıştır. Özdevecioğlu'na göre ise yaşam doyumu, bireyin iş dışı yaşamı hakkındaki duygusal tepkisidir (Özdevecioğlu, 2003: 697). Schmitter'e göre, bireylerin yaşam doyumu birçok şeyden etkilenebilir. Bunlardan bazıları, günlük yaşamdan alınan mutluluk, yaşama yüklenen anlam, amaçlara ulaşma konusunda uyum, pozitif bireysel kimlik fiziksel olarak bireyin kendini iyi hissetmesi, ekonomik güvenlik ve sosyal ilişkilerdir (Aktaran; Tümlü ve Recepoğlu, 2012: 207).

Literatürde örgütsel sessizlik kavramı en sık olarak örgütsel adalet kavramıyla ilişkilendirilmiştir. Örgütsel sessizlik aynı zamanda örgütsel bağlılık, çalışan performansı, örgütsel vatandaşıık davranışı, yıldırma, tükenmişlik, örgütsel sinizm, örgüt kültürü, işten ayrılma niyeti, liderlik tarzı, örgütsel güven kavramlarıyla ilişkilendirilmiştir. Ayrıca çalışmalarda en sık kullanılan ölçek Dyne ve diğerlerinin (2003) hazırladıkları ölçektir. Çalışmalar, örgütsel sessizlik türleri bazında ele alındığında en sık kullanılan boyutun kabullenici sessizlik olduğu sonucuna varılmaktadır (Karakiraz ve diğerleri, 2016: 84-95). Yaşam doyumu kavramı ise sıklıkla iş doyumu kavramı ile ilişkilendirilmiş, aynı zamanda psikolojik dayanıklıık ve tükenmişlik kavramlarıyla da ilişkisini ölçen çalışmaların olduğu görülmektedir.

Örgütsel sessizlik ile yaşam doyumu arasındaki ilişkiyi ölçen çalışmalar incelediğinde Şimşek ve Aktaş'ın Örgütsel Sessizlik ile Kişilik ve Yaşam Doyumu Etkileşimini incelediği araştırmasında kabullenici sessizlik ve savunmacı sessizlik ile yaşam doyumu arasında ters yönlü ve anlamlı bir ilişki bulmuştur. Ayrıca, yaşam doyumunda etkili değişkenin savunmacı sessizlik olduğu, düşük yaşam doyumu olan bireylerin, yüksek olanlara göre kabullenici ve savunmacı sessizlik puan ortalamalarının daha yüksek olduğu sonucuna ulaşmışlardır. Özellikle savunmacı sessizliğin bireyi mutsuz ettiği ve yaşam doyumunu azalttığını da belirlemişlerdir (Şimşek ve Aktaş, 2014: 132-133).

\section{VERI VE YÖNTEM}

Bu bölümünde örgütsel sessizlik ve yaşam doyumuna ilişkin anketin futbol hakemlerine uygulanması sonucunda elde edilen veriler çeşitli istatistiki yöntemler aracılığıyla açıklanmaktadır. Bu araştırmada Türkiye Futbol Federasyonu'nda görev yapan hakemlerin örgütsel sessizlik ve yaşam doyumuna ilişkin algı ve değerlendirmelerine ilişkin görüşlerinin tespit edilmesi; örgütsel sessizlik ve yaşam doyumu arasındaki ilişkinin belirlenmesi amaçlanmaktadır.

Bu çalışmada veriler yüz yüze anket yöntemi kullanılarak toplanmıştır. Anket formunun ilk kısmında, Türkiye Futbol Federasyonu'nda görev yapan hakemlerin demografik özelliklerini belirlemeye yönelik 5 adet soru sorulmuştur. İkinci kısımda ise, örgütsel sessizlik ve yaşam doyumu algısını ölçmeye yönelik toplam 20 adet ifade yer almaktadır. Ankete katılan hakemlerden sorulan her bir ifadeye kendi durumlarına uygun cevap vermeleri istenmiştir. Örgütsel sessizlik algısını ölçmek amacıyla Dyne, Ang ve Botero tarafından (2003) geliştirilen örgütsel sessizlik ölçeği kullanılmıştır. Ölçek savunma amaçlı sessizlik, örgüt yararına sessizlik ve kabullenici sessizlik olmak üzere üç alt boyuttan ve toplam 15 likertli ifadeden oluşmaktadır. Yaşam doyumunu ölçmek için Diener ve arkadaşları tarafından (1985) tarafından geliştirilen, Yetim (1993) tarafından Türkçe'ye uyarlanarak, geçerliliği ve güvenilirliği test edilen yaşam doyumu ölçeği kullanılmıştır. Ölçek tek alt boyuttan ve toplam 5 likertli ifadeden oluşmaktadır. Araştırmanın evrenini, Türkiye Futbol Federasyonu'nda görev yapan hakemler oluşturmaktadır. Araştırmanın örnekleminde olasılı̆̆a dayanmayan örnekleme yöntemlerinden kolayda örnekleme kullanılmıştır (Altunışık vd, 2012:139-141). Araştırmada yüz yüze anket ve kolayda örnekleme metodu 
kullanılarak toplam 118 futbol hakemiyle görüşülmüştür. Anketler incelendikten sonra hatalı olanlar elendikten sonra 114 anket analize tabii tutulmuştur.

Araştırmanın modeli şekil 1'de gösterildiği gibidir. Araştırma modelinde öncelikle örgütsel sessizlik algısının unsurlarına ve yaşam doyumuna yer verilmektedir. Daha sonra demografik faktörlere yer verilerek, örgütsel sessizlik algısının alt boyutu ve yaşam doyumıu arasındaki ilişki saptanmaya çalışılmaktadır.

\section{Şekil 1: Araştırmanın Modeli}

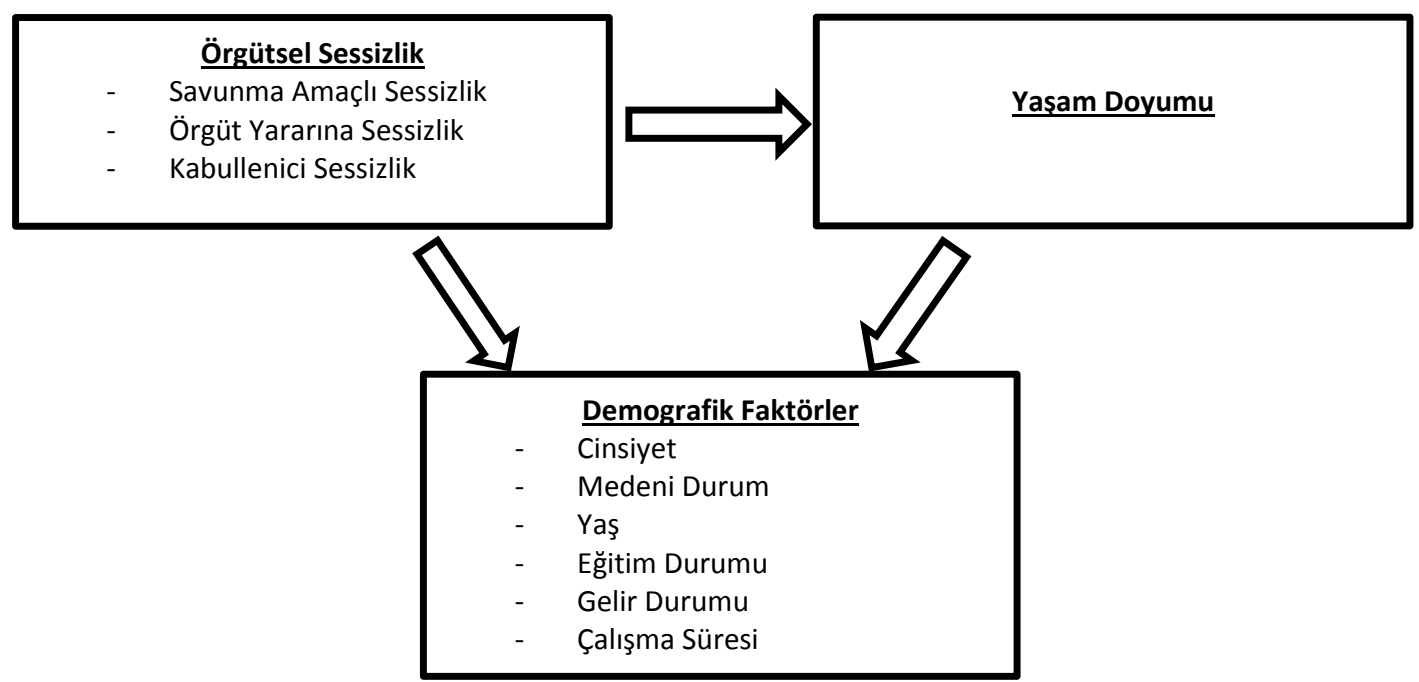

Şekil 1'de yer alan araştırma modelinde örgütsel sessizlik algısının alt boyutları ile yaşam doyumununın alt boyutları arasındaki ilişkiyi incelenmektedir.

\section{BULGULAR VE TARTIŞMA}

Likert Tipi ölçeğe göre hazırlanan soruların güvenilirliği Cronbach Alpha güvenirlilik katsayısı ile ölçülmüştür. Analize göre öğrenen örgütsel sessizlik algısının Cronbach's Alpha değeri ,808 ve yaşam doyumunun ,818 ve genel olarak ise,783 bulunmuştur. Bu değerin $0,60 \leq \alpha<0,80$ değerleri arasında olmasından dolayı ölçek güvenilirdir denilebilir (Kayış, 2010: 405).

Verilerin analizinde, frekans, ortalama ve standart sapma gibi tanımlayıcı istatistiklerden yararlanılmıştır. Araştırmanın hipotezlerini test ederken verilerin normal dağılım göstermemesi nedeniyle mann whitney u testi, kruskal wallis - $\mathrm{h}$ testi ve boyutlar arasındaki ilişkiyi belirlemek için de spearmann korelasyon analizi yapılmıştır. Çalışmada kullanılan örgütsel sessizlik ve yaşam doyumu ölçeklerine daha önce faktör analizi yapıldığı için yeniden faktör analizi yapılmayarak ölçeğin orijinalinde yer alan alt boyutlara göre analizler yapılmıştır. Örgütsel sessizlik; savunma amaçlı sessizlik, örgüt yararına sessizlik ve kabullenici sessizlik olmak üzere üç alt boyut altında, yaşam doyumu ise tek alt boyut altında ölçülmüştür. Çalışmada, futbol hakemlerinin demografik özelliklerine ilişkin cinsiyet, medeni durum, yaş, eğitim durumu, gelir durumu ve çalışma sürelerine ilişkin sorular sorulmuştur. Bu sorulara verilen cevaplar ışığında örneklem grubuna ait demografik bilgiler Tablo 1 de gösterilmiştir.

Tablo 1: Örneklem Grubuna ilişkin Demografik Bilgiler

\begin{tabular}{|c|c|c|c|}
\hline Cinsiyet & Frekans & \% Frekans & Mod \\
\hline Kadın & 10 & 8,8 & \multirow{2}{*}{2} \\
\hline Erkek & 104 & 91,2 & \\
\hline \multicolumn{3}{|c|}{ Medeni Durum } & \multirow{3}{*}{2} \\
\hline Evli & 27 & 23,7 & \\
\hline Bekar & 87 & 76,3 & \\
\hline Yaş & & & 2 \\
\hline
\end{tabular}




\begin{tabular}{|c|c|c|c|}
\hline $20-25$ Yaş & 61 & 53,5 & \\
\hline 26-30 Yaş & 36 & 31,6 & \\
\hline 31 Yaş ve Üzeri & 17 & 14,9 & \\
\hline \multicolumn{3}{|l|}{ Eğitim Durumu } & \multirow{5}{*}{3} \\
\hline Lise & 16 & 14 & \\
\hline Ön Lisans & 19 & 16,7 & \\
\hline Lisans & 66 & 57,9 & \\
\hline Lisansüstü & 13 & 11,4 & \\
\hline \multicolumn{3}{|l|}{ Gelir Durumu } & \multirow{5}{*}{1} \\
\hline $1000-2000 \mathrm{TL}$ & 58 & 50,9 & \\
\hline $2001-3000 \mathrm{TL}$ & 28 & 24,6 & \\
\hline $3001-4000 \mathrm{TL}$ & 17 & 14,9 & \\
\hline 4001 TL ve Üzeri & 11 & 9,6 & \\
\hline \multicolumn{3}{|l|}{ Çalışma Süresi } & \multirow{4}{*}{1} \\
\hline $0-5$ Yll Arası & 78 & 68,4 & \\
\hline 6-10 Yıl Arası & 27 & 23,7 & \\
\hline 11 Yıl ve Üzeri & 9 & 7,9 & \\
\hline
\end{tabular}

Tablo 1 incelendiğinde araştırmaya katılanların büyük bir kısmının erkek (\% 91,2), medeni durumlarının bekar (\% 76,3), 20 25 yaş aralığında (\% 53,5), lisans eğitim durumunda (\% 57,9), 1000-2000 TL arasında (\% 50,9) gelir durumunda ve 0-5 yıl arasında $(\% 68,4)$ çalışma süresinde oldukları görülmektedir. Araştırmada kullanılan değişkenlere ilişkin puan ortalamaları tablo 2'de gösterilmiştir.

Tablo 2: Değişkenlere iliş̧kin Puan Ortalamaları

\begin{tabular}{|l|c|c|c|}
\hline Değişkenler & $\mathrm{N}$ & Ortalama & Standart Hata \\
\hline Örgütsel Sessizlik & 114 & 2,67 &, 546 \\
\hline Savunma Amaçlı Sessizlik & 114 & 1,89 &, 768 \\
\hline Örgüt Yararına Sessizlik & 114 & 3,99 &, 881 \\
\hline Kabullenici Sessizlik & 114 & 1,92 &, 814 \\
\hline Yaşam Doyumu & 114 & 3,14 &, 816 \\
\hline
\end{tabular}

Tablo 2'de değişkenlere ilişkin ortalamalar verilmiştir. Örgütsel sessizlik algısının puan ortalamasının 2,67, yaşam doyumunun ise 3,14 olduğu görülmektedir. Örgütsel sessizlik algısının alt boyutlarına ilişkin puan ortalamaları incelendiğinde savunma amaçlı sessizliği puan ortalamasının 1,89, örgüt yararına sessizlik 3,99 ve kabullenici sessizlik 1,92 puan ortalamasına sahiptir. Değişkenlere ilişkin normal dağılım testi sonuçları tablo 3'te verilmiştir.

Tablo 3: Değişkenlere ilişkin Normal Dağılım Testi

\begin{tabular}{|l|c|c|c|}
\hline Değişkenler & $\mathrm{N}$ & \multicolumn{2}{|c|}{ Kolmogorov-Smirnov Testi } \\
\hline Savunma Amaçlı Sessizlik & 114 & 1,528 & $\mathbf{0 1 9}$ \\
\hline Örgüt Yararına Sessizlik & 114 & 1,601 & $\mathbf{0 1 2}$ \\
\hline Kabullenici Sessizlik & 114 & 1,788 & $\mathbf{, 0 0 3}$ \\
\hline Yaşam Doyumu & 114 &, 849 & $\mathbf{4 6 7}$ \\
\hline
\end{tabular}

Tablo 3'de örneklem grubunun normal dağılıma uygun olup olmadığıyla ilgili test sonuçları gösterilmiştir. KolmogorovSmirnov testi sonuçları incelendiğinde değişkenlerin tamamının $p>, 05$ olmadığı görülmektedir. Bu nednele örneklem grubu normal dağılım göstermemektedir. Değişkenlerin karşılaştırılabilmesi için (2 grup olması durumunda) parametrik olmayan testlerden Mann Whitney $\mathrm{U}$ testi ve ( 3 ve daha fazla grup olması durumunda) Kruskall Wallis $\mathrm{H}$ testleri kullanılarak istatistiksel olarak anlamlı farklılıklar belirlenmiştir. Farklııkların belirlenmesinde anlamlılık seviyesi \% 5 olarak alınmıştır. Araştırmada değişkenler arasında anlamlı farklılık tespit edilenlere yer verilmiştir. Araştırmanın hipotezleri aşağıdaki gibidir:

$\mathrm{H}_{1}$ : Eğitim durumu değişkeni ile savunma amaçlı sessizlik değişkeni arasında anlamlı bir fark vardır.

$\mathrm{H}_{2}$ : Savunma amaçlı sessizlik algısı arttıkça kabullenici sessizlik algısı da artar.

$\mathrm{H}_{3}$ : Örgüt yararına sessizlik algısı arttıkça kabullenici sessizlik algısı azalır.

Mann Whitney $U$ testiyle örgütsel sessizlik ve yaşam doyumunu incelemeye yönelik sorulardan oluşan savunma amaçlı sessizlik, örgüt yararına sessizlik, kabullenici sessizlik ve yaşam doyumu değişkenleri örneklem grubunun cinsiyetleriyle 
karşılaştırılarak bu değişkenler arasında anlamlı bir farklıık olup olmadığı incelenmiştir. Cinsiyet değişkeni ile savunma amaçlı sessizlik $(p=, 992>, 05)$, örgüt yararına sessizlik $(p=, 964>, 05)$, kabullenici sessizlik $(p=, 657>, 05)$ ve yaşam doyumu $(p=, 940>, 05)$ değişkenleri arasında anlamlı bir farklılık olmadığı belirlenmiştir.

Mann Whitney $U$ testiyle örgütsel sessizlik ve yaşam doyumunu incelemeye yönelik sorulardan oluşan savunma amaçlı sessizlik, örgüt yararına sessizlik, kabullenici sessizlik ve yaşam doyumu değişkenleri örneklem grubunun medeni durumlarıyla karşılaştırılarak bu değişkenler arasında anlamlı bir farklılık olup olmadığı incelenmiştir. Medeni durum değişkeni ile savunma amaçlı sessizlik $(p=, 243>, 05)$, örgüt yararına sessizlik $(p=, 899>, 05)$, kabullenici sessizlik $(p=, 612>, 05)$ ve yaşam doyumu $(p=, 823>, 05)$ değişkenleri arasında anlamlı bir farklılık olmadığı belirlenmiştir.

Kruskall Wallis $\mathrm{H}$ testiyle örgütsel sessizlik ve yaşam doyumunu incelemeye yönelik sorulardan oluşan savunma amaçlı sessizlik, örgüt yararına sessizlik, kabullenici sessizlik ve yaşam doyumu değişkenleri örneklem grubunun yaş durumlarıyla karşılaştırılarak bu değişkenler arasında anlamlı bir farklılık olup olmadığı incelenmiştir. Yaş durumu değişkeni ile savunma amaçlı sessizlik $(p=, 487>, 05)$, örgüt yararına sessizlik $(p=, 719>, 05)$, kabullenici sessizlik $(p=, 472>, 05)$ ve yaşam doyumu $(p=, 844>, 05)$ değişkenleri arasında anlamlı bir farklılık olmadığı belirlenmiştir.

Kruskall Wallis $\mathrm{H}$ testiyle örgütsel sessizlik ve yaşam doyumunu incelemeye yönelik sorulardan oluşan savunma amaçlı sessizlik, örgüt yararına sessizlik, kabullenici sessizlik ve yaşam doyumu değişkenleri örneklem grubunun eğitim durumlarıyla karşılaştırılarak bu değişkenler arasında anlamlı bir farklılık olup olmadığı incelenmiştir. Eğitim durumu değişkeni ile örgüt yararına sessizlik $(p=, 709>, 05)$, kabullenici sessizlik $(p=, 170>, 05)$ ve yaşam doyumu $(p=, 906>, 05)$ değişkenleri arasında anlamlı bir farklılık olmadığı, savunma amaçlı sessizlik değişkeni arasında ise anlamlı bir farklılık olduğu belirlenmiş ve anlamlı farklılıkları gösteren Kruskall Wallis $\mathrm{H}$ testi sonuçları Tablo 4'de verilmiştir.

Tablo 4: Eğitim Durumu Değişkeni İle Savunma Amaçlı Sessizlik Değişkenine i̇lişkin Kruskal Wallis H- Testi Sonuçları

\begin{tabular}{|c|c|c|c|c|c|}
\hline & Eğitim Durumu & $\mathbf{N}$ & Sıra Değer Ort. & $x^{2}$ & $\mathbf{P}$ \\
\hline \multirow{4}{*}{$\begin{array}{l}\text { Savunma } \\
\text { Sessizlik }\end{array}$} & Lise & 16 & 67,06 & \multirow{4}{*}{7,809} & \multirow{4}{*}{,05 } \\
\hline & Ön Lisans & 19 & 39,55 & & \\
\hline & Lisans & 66 & 58,91 & & \\
\hline & Lisansüstü & 13 & 64,81 & & \\
\hline
\end{tabular}

Eğitim durumu değişkeni ile savunma amaçlı sessizlik $(p=, 05 \leq, 05)$ değişkeni arasında anlamlı bir fark olduğu tespit edilmiştir. Değişkene sıra değer ortalamasına göre lise eğitim durumunda olanlar en fazla katılırken, ön lisans eğitim durumunda olanlar en az katılım düzeyine sahip katılımcılardır. Lise eğitim durumunda olan katılımcılar örgütsel sessizlik algısında savunma amaçlı sessizliğin önemli bir unsur olduğunu düşünürken, ön lisans eğitim durumunda olan katılımcılar örgütsel sessizlik algısında savunma amaçlı sessizliğin çok fazla önemli olmadığını düşünmektedirler. Savunma amaçlı sessizlik değişkeninde hangi eğitim durumu grupları arasında fark olduğunu ortaya koymak amacıyla Mann Whitney U testi yapılmış çıkan sonuçlar Tablo 5'de verilmiştir.

Tablo 5: Eğitim Durumu Değişkeni İle Savunma Amaçlı Sessizlik Değişkenine iliş̧kin Mann Whitney U Testi Sonuçları

\begin{tabular}{|l|l|l|l|c|c|}
\hline & Eğitim Durumu & $\mathbf{N}$ & Sıra Değer Ort. & $\mathbf{Z}$ & $\mathbf{P}$ \\
\hline \multirow{3}{*}{$\begin{array}{l}\text { Savunma } \\
\text { Sessizlik }\end{array}$} & Lise & 16 & 23,00 & \multirow{2}{*}{$-2,671$} & \multirow{2}{*}{$\mathbf{0 0 7}$} \\
\cline { 2 - 5 } & Ön Lisans & 19 & 13,79 & \multirow{2}{*}{$-2,261$} & \multirow{2}{*}{$\mathbf{0 2 4}$} \\
\cline { 2 - 4 } & Ön Lisans & 19 & 31,82 & 46,22 & \\
\cline { 2 - 4 } & Lisans & 66 & 22 & \\
\hline
\end{tabular}

Eğitim durumu değişkeniyle savunma amaçlı sessizlik değişkeni arasındaki fark, lise ile ön lisans $(p=, 007<, 05)$ ve ön lisans ile lisans $(p=, 024<, 05)$ eğitim durumundaki katılımcılar arasındadır ve katılım düzeyi noktasında bir farklılık bulunmaktadır. Farklılık ön lisans eğitim durumunda olan katılımcılardan kaynaklanmaktadır. Ön lisans eğitim durumundaki katılımcılar diğer eğitim durumu grubundaki katılımcılara göre örgütsel sessizlik algısında savunma amaçı sessizliğin daha az önemli olduğunu düşünmektedirler.

Kruskall Wallis $\mathrm{H}$ testiyle örgütsel sessizlik ve yaşam doyumunu incelemeye yönelik sorulardan oluşan savunma amaçlı sessizlik, örgüt yararına sessizlik, kabullenici sessizlik ve yaşam doyumu değişkenleri örneklem grubunun gelir durumlarıyla karşılaştırılarak bu değişkenler arasında anlamlı bir farklılık olup olmadığı incelenmiştir. Gelir durumu değişkeni ile savunma amaçlı sessizlik $(p=, 417>, 05)$, örgüt yararına sessizlik $(p=, 518>, 05)$, kabullenici sessizlik $(p=, 403>, 05)$ ve yaşam doyumu $(p=, 935>, 05)$ değişkenleri arasında anlamlı bir farklılık olmadığı belirlenmiştir.

Kruskall Wallis $\mathrm{H}$ testiyle örgütsel sessizlik ve yaşam doyumunu incelemeye yönelik sorulardan oluşan savunma amaçlı sessizlik, örgüt yararına sessizlik, kabullenici sessizlik ve yaşam doyumu değişkenleri örneklem grubunun çalışma süreleriyle 
karşılaştırılarak bu değişkenler arasında anlamlı bir farklıık olup olmadığı incelenmiştir. Çalışma süresi değişkeni ile savunma amaçlı sessizlik $(p=, 730>, 05)$, örgüt yararına sessizlik $(p=, 456>, 05)$, kabullenici sessizlik $(p=, 872>, 05)$ ve yaşam doyumu $(p=, 928>, 05)$ değişkenleri arasında anlamlı bir farklılık olmadığı belirlenmiştir.

Örgütsel sessizlik ve alt boyutlarıyla yaşam doyumu arasındaki ilişkiyi belirlemek amacıyla Spearman korelasyon analizi yapılmıştır. Yapılan Spearman korelasyon analizi sonuçları Tablo 6'da verilmiştir.

\section{Tablo 6: Değişkenlere iliş̧in Spearman Korelasyon Analizi Sonuçları}

\begin{tabular}{|l|l|c|c|c|}
\hline Boyut I & Boyut II & N & r & P \\
\hline Savunma Amaçlı Sessizlik & Kabullenici Sessizlik & 114 &, 570 &, 000 \\
\hline Örgüt Yararına Sessizlik & Kabullenici Sessizlik & 114 &,- 305 &, 001 \\
\hline
\end{tabular}

Savunma amaçlı sessizlik ile kabullenici sessizlik değişkenleri arasındaki ilişkiyi belirlemek üzere yapılan spearman korelasyon analizi sonucunda, \% 57 düzeyinde pozitif yönde anlamlı $(p=, 000<, 05)$ orta bir ilişki bulunmuştur. Buna göre savunma amaçlı sessizlik değişkeninin puanı arttıkça kabullenici sessizlik değişkeninin de puanı artmaktadır.

Örgüt yararına sessizlik ile kabullenici sessizlik değişkenleri arasındaki ilişkiyi belirlemek üzere yapılan spearman korelasyon analizi sonucunda, \% 30,5 düzeyinde negatif yönde anlamlı $(p=, 001<, 05)$ zayıf bir ilişki bulunmuştur. Buna göre örgüt yararına sessizlik değişkeninin puanı arttıkça kabullenici sessizlik değişkeninin puanı azalmaktadır.

\section{SONUÇ}

Araştırmada, Türkiye Futbol Federasyonu'nda görev yapan hakemlerin örgütsel sessizlik ve yaş doyumuna yönelik algı ve değerlendirmeleri araştırılmıştır. Araştırmada örgütsel sessizlik algısında savunma amaçlı sessizlik ve kabullenici sessizlik boyutlarının puan ortalamasının düşük olduğu, örgüt yararına sessizlik değişkeni ve yaşam doyumu değişkenlerinin ise yüksek olduğu belirlenmiştir. Hakemlerin savunma amaçlı sessizlik ve kabullenici sessizlik düzeylerinde bir problem olduğu görülmektedir. Bunun nedeni ise futbola gösterilen yoğun ilgi nedeniyle hakemler yoğun bir baskı altında çalışmakta, sık sık eleştirilmekte, çeşitli hakaret ve şiddete maruz kalmaktadırlar. Bu nedenle savunma amaçlı olarak sessiz kalmadıkları ve bu yapılanları da kabul etmemelerinden dolayı bu değişkenlerin puan ortalamalarının düşük olduğu düşünülmektedir. Yaşam doyumu ve örgüt yararına sessizlik değişkenlerinde ise puan ortalamalarının diğer değişkenlere oranla yüksek olmasının nedeni ise örgüt yararına sessiz kaldıkları, ücret, itibar vb etkenler dolayısıyla da yaşam doyumlarının arttığı düşünülmektedir. Yapılan Mann Whitney $U$ ve Kruskall Wallis $\mathrm{H}$ testleriyle örgütsel sessizlik algısının alt boyutları ve yaşam doyumu hakemlerin demografik ve kuruma ilişkin diğer faktörler karşılaştırılarak aralarında anlamlı bir farklılık olup olmadığı, Spearman korelasyon analizi ile örgütsel sessizlik algısının alt boyutları ve yaşam doyumu arasındaki ilişki belirlenmeye çalışılmıştır.

Cinsiyet ve medeni durum değişkenleri ile savunma amaçlı sessizlik, örgüt yararına sessizlik, kabullenici sessizlik ve yaşam doyumu değişkenleri arasında yapılan Mann Whitney $U$ testi sonucunda anlamlı bir farklııı bulunamamıştır. Türkiye Futbol Federasyonu'nda görev yapan kadın hakem sayısının çok fazla olmaması, evli hakem sayısının çok fazla olmaması, vb nedenler dolayısıyla anlamlı farklılığın bulunamadığı düşünülmektedir. Çitli (2015) ve Çakıcı (2008) yapmış oldukları çalışmalarda araştırma sonuçlarımızdan farklı olarak cinsiyet ile örgütsel sessizlik algısı arasında anlamlı bir farklılık belirlemişlerdir. Çitli (2015) yapmış olduğu çalışmada araştırma sonuçlarımızla benzer olarak medeni durum ile örgütsel sessizlik algısı arasında anlamlı bir farklılık olmadığını belirtmiştir. Yetim (1991) yapmış olduğu çalışmada araştırma sonucumuzdan farklı olarak cinsiyet ve medeni durum değiş̧enlerinin yaşam doyumunu etkilediği sonucuna ulaşmıştır.

Yaş, gelir durumu ve çalışma süreleri değişkenleri ile savunma amaçlı sessizlik, örgüt yararına sessizlik, kabullenici sessizlik ve yaşam doyumu değişkenleri arasında yapılan Kruskall Wallis $\mathrm{H}$ testi sonucunda anlamlı bir farklılık bulunamamıştır. Hakem olarak uzun süreler çalışma imkanının olmaması, ücret, vb etkenler dolayısıyla anlamlı farklılık bulunamadığı düşünülmektedir. Uğur (2016) yapmış olduğu çalışmada araştırma sonuçlarımızdan farklı olarak gelir durumu ile örgütsel sessizlik algısı arasında anlamlı bir farklılık belirlemiştir. Eğitim durumu değişkeni ile örgüt yararına sessizlik, kabullenici sessizlik ve yaşam doyumu değişkenleri arasında yapılan Kruskall Wallis $\mathrm{H}$ testi sonucunda anlamlı bir farklılık bulunamamış, savunma amaçlı sessizlik değişkeni ile anlamlı farklıık bulunmuştur. Farklıı̆ı̆ın ön lisans eğitim durumunda olan hakemlerden kaynaklandığı belirlenmiştir. Eğitim durumu, yönetsel, iş olanaklarının sınırlı olması, ücret, vb etkenler dolayısıyla kabullenici sessizlik düzeylerinin diğer eğitim gruplarına göre daha düşük olduğu düşünülmektedir. Uğur (2016) yapmış olduğu çalışmada araştırma sonuçlarımızdan farklı olarak eğitim durumu ile örgütsel sessizlik algısı arasında anlamlı bir farklılık belirlemiştir. Yetim yapmış olduğu çalışmada araştırma sonucumuzdan farklı olarak yaş, ve eğitim durumu değişkenlerinin yaşam doyumunu etkilediği sonucuna ulaşmıştır.

Yapılan Spearman korelasyon analizi sonucunda savunma amaçlı sessizlik ile kabullenici sessizlik değişkenleri arasında pozitif yönde anlamlı orta bir ilişki bulunmuştur. Örgüt yararına sessizlik ile kabullenici sessizlik değişkenleri arasında negatif yönde 
anlamlı zayıf bir ilişki bulunmuştur. Savunma amaçıı sessizlik değişkeninin puanı arttıkça kabullenici sessizlik değişkeninin puanı artarken, örgüt yararına sessizlik değişkeninin puanı arttıkça kabullenici sessizlik değişkeninin puanı azalmaktadır.

Hakemlerin yaşam doyumunu artırıcı etkenlere daha fazla ağırlık verilerek doyum düzeyleri artırılmalıdır. Örgütsel sessizliğe neden olan etkenler belirlenerek bu etkenlerin ortadan kaldırılabilmesi için çalışmalar yapılmalıdır. Bundan sonra yapılacak çalışmalarda farklı branşlardaki hakemlerin örgütsel sessizlik algı düzeylerinin farklılık gösterip göstermediğiyle, örgütel bağlıık ve iş doyumu bağlamında ne gibi biçimler aldığı araştırılabilir.

\section{KAYNAKLAR}

Altunışık, R., Coşkun, R., Bayraktaroğlu S. ve Yıldırım, E. (2012) Sosyal bilimlerde araştırma yöntemleri (7.b), Sakarya: Sakarya Yayıncılık.

Baydar, H. Ö. (2002). Illkokul ve ortaokulda görev yapan beden eğitimi öğretmenlerinin yaşam doyumu ve mesleki tükenmişlik düzeylerinin incelenmesi, Yayımlanmamış yüksek lisans tezi, Gazi Üniversitesi, Ankara.

Çakıcı, A., (2007). Örgütlerde Sessizlik: Sessizliğin Teorik Temelleri ve Dinamikleri. Çukurova Üniversitesi Sosyal Bilimler Enstitüsü Dergisi, vol. 16 , no. 1 , p. $145-162$.

Çakıcı, A., (2008). Örgütlerde Sessiz Kalınan Konular, Sessizliğin Nedenleri ve Algılanan Sonuçları Üzerine Bir Araştırma. Çukurova Üniversitesi Sosyal Bilimler Enstitüsü Dergisi, vol. 17, no. 1, p. 117- 134.

Çakıcı, A., (2010). Örgütlerde İş gören Sessizliği Neden Sessiz Kalmayı Tercih Ediyoruz? Ankara: Detay Yayıncılık.

Çakıcı, A., ve Aysen, B. (2014). Örgütlerde Yönetici Sessizliği Mümkün müdür? Keşifsel Bir Araştırma. Niğde Üniversitesi İktisadi ve İdari Bilimler Fakültesi Dergisi, vol. 7, no. 1, p. 107-125.

Çitli, i. ì. (2015). Örgütsel sessizlik ile tükenmişlik arasındaki ilişki ve bir araştırma, Yayımlanmamış yüksek lisans tezi, Bahçeşehir Üniversitesi, İstanbul.

Diener, E. (1984). Subjective well-being. Psychological Bulletin, vol. 95, p. 542-575.

Diener, E. (2000). Subjective well-being: The science of happiness and a proposal for a national index. American Psychologist, vol. 55 no. 1, p. 34-43.

Diener, E.,Biswas-Diener, R. (2001). Making the best of a bad situation: Satisfaction in the slums of Cal-cutta. Social Indicators Research, vol. 55 , p. 329-352.

Dyne, L. V., S. Ang ve I. C. Botero. (2003). Conceptualizing Employee Silence and Employee Voice as Multidimensional Constructs. Journal of Management Studies, vol. 40, no. 6, p. 1359-1392.

Eryılmaz, A., ve Öğülmüş, S. (2010). Ergenlikte öznel iyi oluş ve beş faktörlü kişilik modeli. Ahi Evran Üniversitesi Eğitim Fakültesi Dergisi, vol. 11, no. 3, p. 189-20.

Miliken, F. J., Morrison, E. W. Ve Hevlin, P. F. (2003). Organizational Silence: A Barrier to Change and Development in a Pluralistic World. Academy of Management Review, vol. 25, no. 4, p. 706-725.

Özdevecioğlu, M. (2003). İş Tatmini ve Yaşam Tatmini Arasındaki İlişkinin Belirlenmesine Yönelik Bir Araştırma. 11.Yönetim ve Organizasyon Kongresi, Afyon.

Özgen, I., ve Sürvegil, O. (2009). Örgütlerde Sessizlik Olgusu ve Turizm İşletmeleri Açısından Değerlendirilmesi içinde Sabuncuoğlu, Z. (Ed.). Turizm İşletmelerinde Örgütsel Davranış, Bursa: MKM Yayınları, p. 300-328.

Pinder, C. C. ve K.P. Harlos. (2001). Employee Silence: Quiescence and Acquiescence as Responses to Perceived Justice içinde Research in Personnel and Human Resources Management, vol. 20, p. 331-369.

Şimşek, E. ve Aktaş, H. (2014). Örgütsel sessizlik ile kişilik ve yaşam doyumu etkileşimi: Kamu sektöründe bir araştırma. Anadolu Üniversitesi Sosyal Bilimler Dergisi, vol. 14, no. 2, p. 121-136.

Taşkıran, E., (2011). Liderlik ve Örgütsel Sessizlik Arasındaki Etkileşim, İstanbul: Beta Yayınevi.

Uğur, S. S. (2016). Kişilik tipolojileri ne göre çalişanlarin örgütsel sessizlik algilamalari: kamu ve özel kesimde bir araştirma, Yayımlanmamış doktora tezi, İnönü Üniversitesi, Malatya.

Tümlü, G. Ü., ve Recepoğlu, E. (2013). Üniversite akademik personelinin psikolojik dayanıklılık ve yaşam doyumu arasındaki ilişki. Yükseköğretim ve Bilim Dergisi, vol 3, no. 3, p. 205-213.

Veenhoven, R. (1996). The study of life satisfaction. In: W. E. Saris, R. Veenhoven, A. C. Scherpenzeel, \& B. Bunting (Eds). A comparative study of satisfaction with life in Europe. Budapest: Eötvös University Press.

Yetim, Ü. (1991). Kişisel projelerin organizasyonu ve örüntüsü açısından yaşam Doyumu. İzmir: Ege Üniversitesi Sosyal Bilimler Enstitüsü Yayınlanmamış Yüksek Lisans Tezi.Kayış, A. (2010) Güvenilirlik analizi. Ş. Kalaycı (Ed.) SPSS uygulamalı çok değişkenli istatistik teknikleri. (5.b), (ss.404-419). Ankara: Asil Yayın Dağıtım. 